all sorts of permutations and possibilities that should improve quality.

There are several basic criteria against which any new structure should be judged. Any arrangement should optimise the chance of enhancing the competence and performance of all general practitioners and should help promote a culture for excellence in all practices. It should achieve first class vocational training and positively help established doctors to keep abreast of their subject. The structure should strengthen the academic base of general practice yet be flexible, so encouraging experiment and innovation. It should create the best conditions possible for interspecialty and multidisciplinary working. The objectives should be clear and the methods clearly costed so that NHS management would know the true price of sound educational programmes. The taxpayer too needs to be sure of value for money.

In the coming dialogue on such matters between the profession and the NHS it is essential that general practice should first sort out its own objectives and then secure support and understanding for these within the broader church of medicine, particularly among the postgraduate deans and specialty advisers who will be concerned in implementation. The other specialties of medicine are themselves moving in a similar direction, ${ }^{10}$ so there is much to be gained by building on shared principles and experience. In the era of managed health care there never was a clearer need for the medical profession as a whole to have its own strong and coherent sense of direction for medical education.

DONALD IRVINE Regional adviser in general practice

Regional Postgraduate Institute for

Medicine and Dentistry,

The University,

Newcastle upon Tyne NE2 4AB

1 Royal College of General Practitioners. An academic plan for general practice. London: RCGP, 1990 (Occasional paper 49.)

2 Pereira Gray DJ. Two sides of the coin. Postgraduate Education for General Practice 1993;4:85-8. 3 Audit Commission. Practices make perfect: the role of the family health services authority. London: HMSO, 1993.

Moore T. The case of the disappearing generalist: does it need to be solved? Milbank Quarterly 1992;70:362-79.

5 Irvine DH. General practice in the 1990's: a personal view on future developments. Br $f$ Gen Pract 1993;43:121-25.

6 General Medical Council. Working party on the review of 1980 recommendations on basic medical education. London: GMC, 1991

General Medical Council. Recommendations on general clinical training. London: GMC, 1992.

8 Working Group on Specialist Medical Training. Report. London: Department of Health, 1993. (Chairman K Calman.)

Allen J, Wilson A, Fraser R, Pereira Gray DJ. The academic base for general practice: the case for change. $B M 7$ 1993;307:719-22.

10 Kerr DNS, Jones SAM, Easman CSF. Continuing medical education: experience and opinions of consultants. BMF 1993;306:1398-402.

\title{
Rituals in antenatal care-do we need them?
}

\section{$A$ conflict between consumer demand and cost effectiveness}

Pregnant women in Britain traditionally have an average of 15 antenatal checks during pregnancy..$^{1-3}$ At each visit, the woman is likely to be weighed and have her blood pressure and fundal height measured and her urine tested for glucose and protein. ${ }^{1}$ Someone will attempt to hear the fetal heart with either a Pinard stethoscope or a portable Doppler ultrasound machine, and the mother will be asked about fetal movements. Almost all of these routine procedures are of dubious value.

Body mass index (weight in kg divided by (height in $\mathrm{m})^{2}$ ) in early pregnancy identifies women at an increased risk of producing an infant that is small for gestational age, ${ }^{4}$ and good weight gain (up to $15 \mathrm{~kg}$ ) ameliorates the outcome in these women..$^{5-7}$ The significance of weight gain in women of normal or above average body mass index is, however, uncertain, ${ }^{6}$ and a recent critique of the Institute of Medicine's recommendations for weight gain in pregnancy commented that "the predictive value of maternal weight gain is low." The National Perinatal Epidemiology Unit in Oxford has failed to find evidence of the value of weight gain as a screen for poor fetal growth or incipient pre-eclampsia and has suggested reassessment of the need for routine weighing of pregnant women. ${ }^{8}$

In studies of routine antenatal care the assessment of uterine size, even when performed with a tape measure, has a sensitivity of only $15-30 \%$ in detecting fetuses whose weight for gestational age is below the 10th centile. ${ }^{9}$ In any case, morbidity in labour and the neonatal period is probably related as much to growth velocity as size per se, ${ }^{10}$ and both are best detected by serial ultrasonographic measurements of fetal abdominal circumference. ${ }^{11}$

Testing the urine for glucose is not an effective screening method for gestational diabetes. Two thirds of normal pregnant women have glycosuria at some time during pregnancy ${ }^{12}$; restricting glucose tolerance testing to women who have repeated glycosuria identifies less than one tenth of women with chemical diabetes of pregnancy. ${ }^{13} \mathrm{~A}$ single blood sugar estimation one hour after a glucose load is probably the most cost effective screening method..$^{13}$

Although testing the urine for protein is an important step in detecting pre-eclampsia, a positive dipstick test for protein in the presence of normotension is likely to be due to contamination of the sample with vaginal discharge. Without symptoms a positive dipstick test for protein is unlikely to indicate an occult urinary tract infection, and in any case routine screening for bacteriuria is probably not cost effective in the general population in Britain. ${ }^{14}$ Measuring the urinary albumin:creatinine ratio at booking may prove to be the best screening test for occult renal dysfunction. ${ }^{15}$

Listening for the fetal heart is another ritual that has recently been re-examined ${ }^{16}$; no value other than reassurance of the mother was found. Similar information can be obtained by palpating, or the mother reporting, fetal movements. In a randomised controlled trial of 68000 women more detailed daily fetal movement counting did not reduce antepartum stillbirths. ${ }^{17}$

Hall et al suggested as long ago as 1980 that for most pregnant women no more than five full antenatal checks were necessary, with more frequent measurement of blood pressure alone in the last trimester. ${ }^{18}$ In 1985 Marsh reported that in general practice he had been able to reduce the number of consultations from an average of 15 to eight in nulliparous women and six in multiparous women, ${ }^{3}$ although he recommended that the time saved be used to provide longer, more structured consultations. Unfortunately, prospective trials have failed to show any benefit from increased education and social support from professionals during pregnancy. ${ }^{19} 20$

Why then has such a pattern of largely ineffective ritual persisted in antenatal care? The most probable reason is that women like it and find it reassuring. Indeed the main finding in one study of social support from midwives who made a minimum of three home visits, were on call through radiopagers, and were readily available on the telephone was that 
$80 \%$ of the women appreciated having someone to listen to their problems; there was little change in the physical outcome of the pregnancy. ${ }^{21}$ In addition, I suspect that midwives and doctors are haunted by the fear that they might miss something (or at least be accused of missing something) if they don't conform to the expected ritual.

Current moves to demedicalise and decentralise childbirth, potentially providing more continuity of care, are necessitating radical changes in the organisation of maternity care..$^{22}$ They should be seen as an opportunity to discard outdated rituals, rather than simply to transfer them from doctors to midwives. The time saved could be channelled into prospective trials of more promising interventions, such as programmes of smoking cessation, and increasing the time available for training in counselling about the many new screening tests becoming available in early pregnancy.

PHILIP STEER

Professor and head

Academic Department of Obstetrics and Gynaecology,

Charing Cross and Westminster Medical School,

London SW $109 \mathrm{NH}$

1 Bull MJV. Maternal and fetal screening for antenatal care. BMF 1990;300:1118-20

2 Coope JK, Scott AV. A programme for shared maternity and child care. BMf 1982;284:1936-7.

3 Marsh GN. New programme of antenatal care in general practice. $B M \mathcal{F} 1985 ; 291: 646-8$.
4 Van der Spuy Z, Steer PJ, McCusker M, Steele SJ, Jacobs HS. Outcome of pregnancy in underweight women after spontaneous and induced ovulation. $B M Y$ 1 1988;296:962-5.

5 Seidman DS, Ever-Hadani P, Gale R. The effect of maternal weight gain in pregnancy on birth weight. Obstet Gynecol 1989;74:240-6.

6 Abrams BF, Laros RK. Prepregnancy weight, weight gain, and birth weight. Am $\mathcal{f}$ Obstet Gynecol 1986;154:503-9.

7 Parker JD, Abrams B. Prenatal weight gain advice: an examination of the recent prenatal weight gain recommendations of the Institute of Medicine. Obstet Gynecol 1992;79:664-9.

8 Dawes MG, Green J, Ashurst H. Routine weighing in pregnancy. BMf 1992;304:487-9.

9 Backe B, Nakeling J. Effectiveness of antenatal care: a population based study. $\mathrm{Br} f$ Obstet Gynaecol 1993;100:727-32.

10 Danielian PJ, Allman ACJ, Steer PJ. Is obstetric and neonatal outcome worse in fetuses who fail to reach their own growth potential? Br 7 Obstet Gynaecol 1992;99:452-4.

11 Soothill PW, Ajayi RA, Campbell SH, Nicolaides KH. Prediction of morbidity in small and normally grown fetuses by heart rate variability, biophysical profile score and umbilical artery normally grown fetuses by heart rate variability, bio

12 Lind T, Hytten FE. The excretion of glucose during normal pregnancy. $\mathcal{f}$ Obstet Gynaecol B Commonw 1972;79:961-5.

13 Gillmer MDG, Oakley NW, Beard RW, Nithyananthan R, Cawston M. Screening for diabetes during pregnancy. Br $\mathcal{F}$ Obstet Gynaecol 1980;87:377-82.

14 Campbell-Brown M, McFadyen IR, Seal DV, Stephenson ML. Is screening for bacteriuria in pregnancy worthwhile? $B M \mp$ 1987;294:1579-82.

15 Perry IJ, Gosling P, Sanghera K, Churchill D, Luesley DM, Beevers DG. Urinary microalbumi excretion in early pregnancy and gestational age at delivery. $B M F$ 1993;307:420-1.

16 Sharif $\mathrm{K}$, Whittle $\mathrm{M}$. Routine antenatal fetal heart rate auscultation: is it necessary? $\mathcal{f}$ Obstet Gynaecol 1993;13:111-3.

17 Grant A, Elbourne D, Valentin L, Alexander S. Routine formal fetal movement counting and risk f antepartum late death in normally formed singletons. Lancet 1989;ii:345-9.

$18 \mathrm{Hall}$ MH, Chng PK, MacGillivray I. Is routine antenatal care worthwhile? Lancet 1980;i:78-80.

19 Spencer B, Thomas H, Morris J. A randomised controlled trial of the provision of a social support service during pregnancy: the South Manchester family worker project. Br $\mathcal{f}$ Obstet Gynaecol 1989;96:281-8.

20 Konte JM, Creasy RK, Laros RK. California north coast preterm birth prevention project. Obstet Gynecol 1988;71:727-30.

21 Oakley A, Rajan L, Grant A. Social support and pregnancy outcome. Br $f$ Obstet Gynaecol 1990;97:155-62.

22 Lilford R. Midwives to manage uncomplicated childbirth. BMf 1993;307:339-40.

\title{
The routine six week postnatal vaginal examination
}

\author{
Forget it
}

We have been schooled to believe that routine postnatal vaginal examinations at six weeks are necessary, and current obstetric and midwifery textbooks perpetuate this teaching. We are told how to examine for supposed abnormalities and what correction may or may not be needed. This advice is based on supposition and has now been challenged. Strube pointed out that this routine vaginal examination is illogical. ${ }^{1}$ Bowers found that women viewed discussion concerning their baby and how they felt and contraceptive advice as more important than a physical examination. ${ }^{2}$

Sharif $e t$ al studied the case records of 150 women attending their doctor for postnatal checks. ${ }^{3}$ Although only 25 had a specific indication, they all had a vaginal examination. An "abnormality" was found in only six of the 125 women who had a routine examination without any specific indication: three had an asymptomatic "bulky" uterus and three had cervical ectopy. None of these patients had any treatment.

Some doctors and midwives recommend that women should not have sexual intercourse until after the routine vaginal examination at six weeks but most women resume sexual intercourse before the postnatal visit-usually between two and four weeks after birth. ${ }^{45}$ Some women experience discomfort or bleeding from their vaginal or perineal wounds, but they do not experience important harm.

Some women may have been conditioned to think that a vaginal examination is important, but most see it as a necessary evil rather than a helpful experience. ${ }^{6}$ The examination consumes resources, requires a chaperone for male doctors, and uses time that would be better spent on counselling; it should therefore be done only when a specific indication exists. These are mostly obvious and include abnormal discharge and dyspareunia. Women wanting reassurance and those who wish to combine their postnatal visit with the insertion of an intrauterine device or a repeat cervical smear test should also be examined. In addition, those few women complaining of stress incontinence should be examined, mainly to ensure that their endeavours to exercise and strengthen the pelvic floor muscles are directed at the right set of muscles.

The postnatal visit at six weeks is an important opportunity to consider more general disorders such as backache and depression and to discuss infant feeding and immunisation and contraception. Ideally, at these visits the women would see both the general practitioner and the community midwife. A few patients (those with serious complications of pregnancy or childbirth, resulting in serious illness or death of the baby) should also see their consultant obstetrician at this time. Women who were delivered by caesarean section for the first time would benefit from seeing a consultant, who could arrange $x$ ray pelvimetry or computed tomography of the pelvis to improve advice regarding the desirable mode of any future deliveries.

The postnatal visit at six weeks is an important tradition that should continue. But the emphasis should change, with vaginal examination being limited to women with specific indications.

TONY NOBLE

Royal Hampshire County Hospital,

Winchester,

Hampshire SO22 5DG

1 Strube G. A woman's health. London: Croom Helm, 1980.

2 Bowers J. Is the six-weeks postnatal examination necessary? Practitioner 1985;229:1113-5.

3 Sharif $\mathrm{K}$, Clarke $\mathrm{P}$, Whittle $M$. Routine six weeks postnatal vaginal examination: to do or not to do? 7 Obstet Gymaecol 1993:13:251-2.

f Obstet Gynaecol 1993;13:251-2. Am f Obstet Gynecol 1976;126:41 6-7.

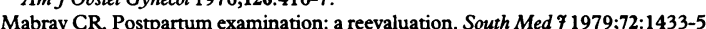

6 Swaffield L. Today's mother. Nursing Times 1983 Mar 9:59-60. 